\title{
SOME NOTES ON TRYPARSAMIDE THERAPY IN A VENEREAL DISEASE CLINIC
}

By T. S. KEITH, M.B., and H. S. Le MARQUAND, M.D.

IN December, I926, we began to use tryparsamide in the treatment of neurosyphilitic out-patients in the Venereal Disease Department of the Royal Berkshire Hospital.

While no conclusive results can be claimed, we have been so impressed with the resulting improvement in the majority of cases, that we wish to add our quota of evidence to the value of the careful use of this drug.

Nature of the Treatment.-A course of treatment consisted of six intravenous injections at weekly intervals of $2 \mathrm{gm}$. of Tryparsamide in Io c.c. of distilled water. After an interval of two or three months a second course was usually begun. In some cases a third and fourth course were added.

In a number of cases (noted in the tables) a course of metallic bismuth was given coincidently with the Tryparsamide. This consisted of the weekly injection for twelve weeks of I c.c. of Bismostab (metallic bismuth suspension) into the gluteal muscles.

During the period under review the cases had no other treatment, except that two cases of G.P.I. were treated by malaria.

Classification of the Cases.-We have classified our cases as follows :-

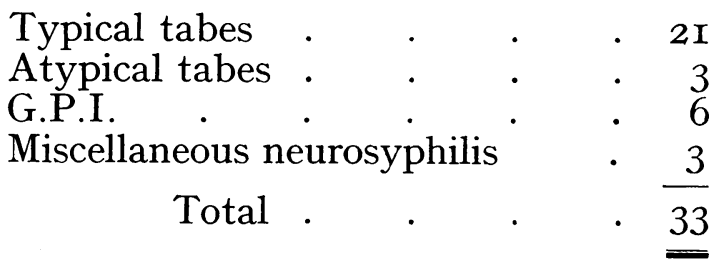

These include all the cases of neurosyphilis regularly attending the Clinic, so that the results are not selected. 


\section{SOME NOTES ON TRYPARSAMIDE THERAPY}

Of the twenty-four cases classed as tabes, twenty-one are very definite pictures of the disease in which the diagnosis is not in doubt. The three remaining cases show one or more signs of tabes, together with a positive Wassermann reaction. These cases are probably best classified as tabes when one remembers the many atypical forms of the disease and the fact that one sign or symptom may precede the development of the complete disease by many years. This aspect of the subject was recently discussed in a paper by I. T. Davies, ${ }^{1}$ where further references to the literature are given.

The G.P.I. cases are all in the early stages, but no case is included under this heading in which the diagnosis can be disputed.

The cases under the heading of Miscellaneous did not fall readily into any group. They were undoubted syphilitics; one gave a history of the primary stage, all had had positive Wassermann reactions. Two complained of persistent headache, but showed no neurological signs ; the third had had ptosis, which cleared up on treatment, but suffered from pains in the legs.

As a matter of interest, the notes of all cases attending the Clinic for syphilis were gone through, and all those patients who showed a persistent Wassermann reaction were re-examined, with the discovery of several unsuspected neurological cases. The other cases which showed persistent positive Wassermann reactions (fifteen in number) were treated to see if the reaction would be influenced. As these results are not germane to the subject of the present paper, they are only included in the table showing complications.

Precautions.-A thorough physical examination was made before the treatment was commenced. Particular attention was paid to the eye refiexes, state of the vision and of the fundus.

Any case suggestive of eye complications was referred to the ophthalmic surgeon for his opinion before commencing treatment.

Any patient complaining of any eye symptom whatever had his Tryparsamide stopped forthwith and his fundus re-examined. If, after a rest, the eye symptoms passed off, Tryparsamide was given again in half-doses. A further c pmplaint of eye symptoms was taken as an absolute (p)ntra-indication to Tryparsamide. 


\section{BRITISH JOURNAL OF VENEREAL DISEASES}

\section{REsults of TREATMENT \\ Tabetic Cases}

Our criterion of improvement is based upon the clinical condition of the patient, upon the amelioration of his symptoms and his ability to live a more normal life, for as our patients were seen in an out-patient department, it was not possible to correlate carefully the clinical and the serological findings.

Considering Tables I. and IV., we see that out of twenty-four cases, eleven showed slight and seven marked

TABLE I

Results

\begin{tabular}{|c|c|c|c|c|c|c|}
\hline $\begin{array}{l}\text { No. of } \\
\text { Cases. }\end{array}$ & Diagnosis. & $\begin{array}{c}\text { Slightly } \\
\text { Improved. }\end{array}$ & $\underset{\text { Improved. }}{\text { Much }}$ & Unchanged. & Worse. & $\begin{array}{l}\text { Ceased to } \\
\text { Attend. }\end{array}$ \\
\hline 24 & Tabes & II & 7 & 2 & 2 & 2 \\
\hline 3 & $\begin{array}{l}\text { Miscellaneous } \\
\text { Neuro-syphilis }\end{array}$ & $\mathbf{I}$ & 2 & I & I & - \\
\hline 6 & G.P.I. & 一 & 6 & 一 & - & 一 \\
\hline 33 & Total . & 12 & I3 & 3 & 3 & 2 \\
\hline
\end{tabular}

improvement; when the chronic nature of these cases is borne in mind, we think that this result is satisfactory.

Amongst the markedly improved group we noted amelioration of most of the cardinal symptoms of tabes, particularly the ataxy and the pains. Even when the gross symptoms were not much relieved almost all the patients showed an improvement in general health, and compared the results of the Tryparsamide injections very favourably with the results of their previous treatment.

In several cases Tryparsamide caused a sudden improvement in a chronic trophic ulcer. We have not scen any mention of this in a previous communication.

In the opinion of Neymann and Singleton, ${ }^{2}$ favourable results are usually obtained only by intensive and extensive treatment with Tryparsamide ; in our cases, on the contrary, those patients who were benefited appeared to improve almost from the start of the treatment.

Moore and Sutton ${ }^{3}$ state that those patients who have received prolonged treatment with mercury and the 


\section{SOME NOTES ON TRYPARSAMIDE THERAPY}

arsphenamines show more striking gains with Tryparsamide than those who have received no preparatory treatment. This is not borne out in our cases; the seven cases of tabes showing marked improvement had had less previous treatment than the eleven cases showing slight improvement.

Only one of our G.P.I. cases had had much previous treatment, yet they all showed great improvement.

A few of the Tabetic cases are worth reporting :-

No. I4.-Male, aged 23. Infection was denied. Mother has a strongly positive Wassermann and 84 Sigma units. Father died of G.P.I. No brothers or sisters.

Attended 24.2.26, showing ataxia, absent ankle jerks and knee jerks and the right optic disc was a suspicious

TABLE II

Amount of Treatment with Tryparsamide

\begin{tabular}{r|l|c|c|c|c|c}
\hline $\begin{array}{c}\text { No. of } \\
\text { Cases. }\end{array}$ & \multicolumn{1}{|c|}{ Diagnosis. } & $\begin{array}{c}\text { One } \\
\text { Course. }\end{array}$ & $\begin{array}{c}\text { Two } \\
\text { Courses. }\end{array}$ & $\begin{array}{c}\text { Three } \\
\text { Courses. }\end{array}$ & $\begin{array}{c}\text { Four } \\
\text { Courses. }\end{array}$ & $\begin{array}{l}\text { Other treatment } \\
\text { Simultaneous. }\end{array}$ \\
\hline 24 & Tabes . & I5 & 7 & I & I & 5 Bismuth \\
6 & G.P.I. . & 2 & 2 & I & I & $\begin{array}{l}\text { 2 Bismuth } \\
\text { 2 Malaria }\end{array}$ \\
3 & $\begin{array}{l}\text { Miscellaneous } \\
\text { Neuro-syphilis }\end{array}$ & 3 & - & - & - & - \\
\hline
\end{tabular}

grey colour. Treatment with N.A.B. and bismuth was given for six months with some improvement, when the patient ceased attending for eighteen months. After this period he was found to be almost blind in the right eye and the left disc was a grey colour.

A course of bismuth was given, but the eyes failed rapidly, becoming completely blind 2.7 .28 ; at that time the ataxia was very severe and he suffered from gastric crises. Tryparsamide was now started and caused an immediate improvement. The ataxia was very much lessened, the pains markedly diminished, the patient got up from his bed, where he had been lying practically helpless, and is now attending a school for the blind.

In view of the marked effect of only one course of Tryparsamide, it seems to us an open question whether it should not have been given before, despite the failing vision. 


\section{BRITISH JOURNAL OF VENEREAL DISEASES}

No. II.-Male, aged 37. First attended in I925. A typical case of tabes. The first sign of the disease that the patient noticed was difficulty in playing the bassoon, owing to the loss of sense of position of the fingers.

$\mathrm{He}$ was given a large amount of routine treatment.

9.3.27. The first course of Tryparsamide was given with good results. Early in I928 a second course was given, with equally satisfactory results. He then looked a different man compared with his condition before Tryparsamide. In June, I928, a third course of the drug was started, but after the third injection he complained

TABLE III

Complications

\begin{tabular}{c|c|c|c|c|c|c|c}
\hline $\begin{array}{c}\text { No. of } \\
\text { Cases. }\end{array}$ & Jaundice. & Dermatitis. & $\begin{array}{c}\text { Head- } \\
\text { aches. }\end{array}$ & Sickness. & $\begin{array}{c}\text { Transient } \\
\text { Eye } \\
\text { Symptoms. }\end{array}$ & Influenzal. & $\begin{array}{c}\text { Exacer- } \\
\text { bations. }\end{array}$ \\
\hline I5 & 3 & 2 & I & I & 4 & I & 3 \\
\hline
\end{tabular}

Jaundice.-Treated with thiosulphate, all recovered. One case noted as having an exacerbation had jaundice $q . v$.

Dermatitis.-Treated with thiosulphate, all recovered. One case, see above.

Sickness no more severe than is met with after N.A.B.

Eye Symptoms were all transient. Blurred vision, floating spots, etc. Any complaint of any sort of eye trouble was noted, no matter how trivial.

Influenzal.-Trivial, may well have been a mild cold.

Exacerbations.-See special note.

of intense pain in the right foot. The treatment was stopped for a month and then recommenced, but the pains persisted. On 26.9.28 it was noticed that the patient showed wasting of the right calf and right gluteal muscles and the left thigh. In November, I928, he developed worse pains than ever before following the last of the injections.

He shows an increase of his ataxia, but no very marked loss of power. It is difficult to know to what factor to attribute the increase of pain and wasting. Exacerbation of tabetic symptoms is generally reported to occur during the first course of Tryparsamide.

20.II.28. On the supposition that the condition was the direct result of Arsenical therapy, three injections of 


\section{SOME NOTES ON TRYPARSAMIDE THERAPY}

Sodium Thiosulphate (0.6, 0.6 and 0.9 gm.) were given. Each injection was followed by an acute attack of pain lasting two to three hours. No noticeable improvement resulted ; the patient is still under observation.

No. 2.-Male, aged 28. Stableman. Reported to the Clinic in 1920 with a typical primary chancre; spirochætes found; Wassermann ++ . Treated with N.A.B. After six months he ceased to attend, returning after another six months with a right facial paralysis, got by "travelling in a draughty horse box." $\mathrm{He}$ was given more N.A.B. and mercury and iodide by the mouth, treatment being continued for five years from the date of his first attendance. During this time he had seven courses of various arsenobenzol compounds and one course of bismuth. He then ceased to attend for eighteen months and returned with typical tabetic symptoms, which had been treated as "fibrositis " for three months.

He was at once put on Tryparsamide and rapidly improved; he can ride any horse and do his work, but he cannot run with any certainty or comfort and he is unsteady after dark.

While away he married and has a son. Both wife and son have negative Wassermanns.

\section{Results in the G.P.I. Cases}

These results (Tables I. and IV.) are interesting and encouraging. All the cases were seen in the early stages of the disease, but no case has been called G.P.I. in which the diagnosis could be disputed. Immediate benefit was received from Tryparsamide in each case. Later, in two cases malaria and in three cases bismuth was added to the treatment, but we think that the main credit is due to the Tryparsamide. Five of the cases of G.P.I. have returned to work; in three of them it is impossible to find any disability whatever.

The cases are of sufficient interest to report briefly. In one case, No. 32, there is a definite improvement in the physical signs, the only case in the whole series to show this.

No. 22.-Male, ag€d 44. First seen 5.3.27, when he had a year's history.

Mentally.-Patient showed a fatuous emotional manner, very impaired ideation and memory, and considerable excitement.

จ.D. 
BRITISH JOURNAL OF VENEREAL DISEASES

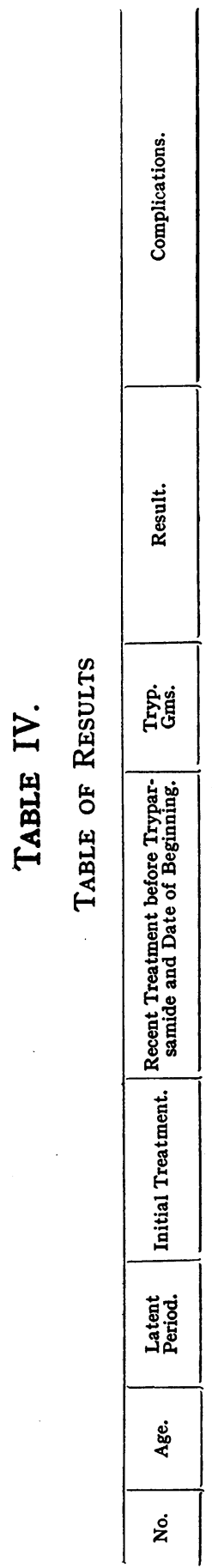

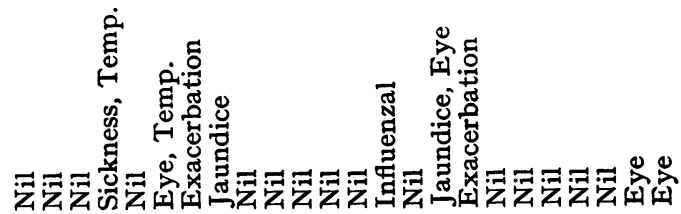

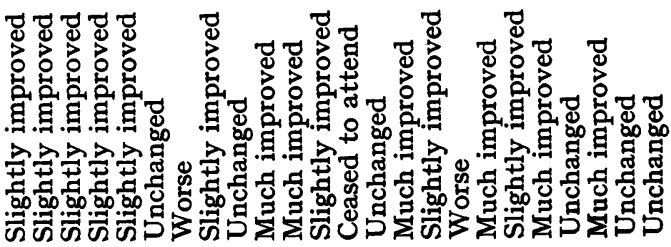

- $\dot{\varphi} \dot{m} \dot{m} \quad \dot{m} \dot{m}$

: A

\&

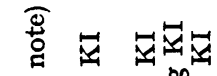

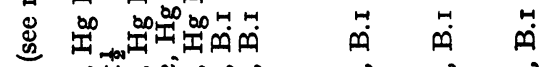

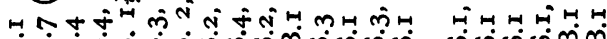
vivivivivivivivivi vivivin \&

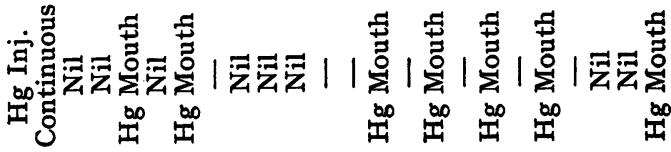

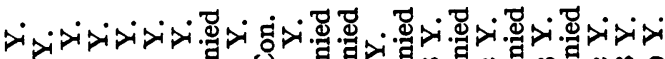

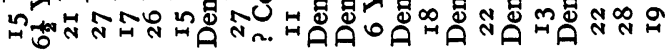

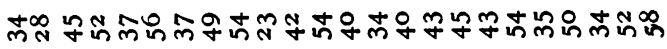

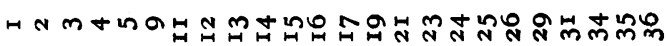


SOME NOTES ON TRYPARSAMIDE THERAPY

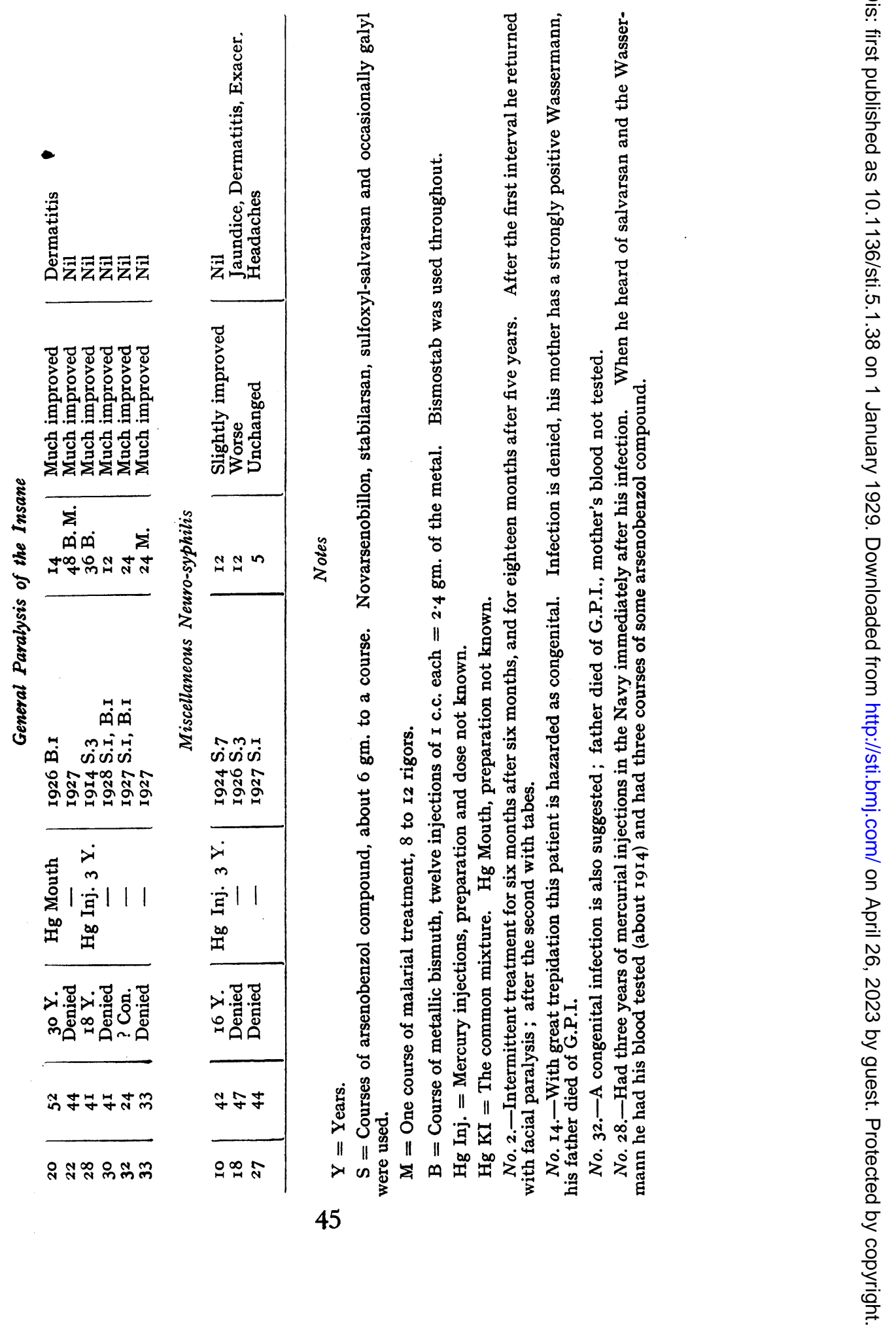




\section{BRITISH JOURNAL OF VENEREAL DISEASES}

Physically.-Absent ankle jerks, absent right knee jerk, Argyll Robertson pupils.

Blood.-Wassermann ++ .

He was treated with Tryparsamide, gm. I2. Mental improvement was very marked by 8.6.27. Physical signs unchanged. A second course of Tryparsamide started I5.6.27, together with bismuth. Tryparsamide I2 gm., bismuth I3 c.c., had been given by 3I.8.27. Considerable improvement was noted, but to give him every chance we advised malaria treatment, which was carried out at the Maudsley Hospital, where he had twelve rigors, February, I928. Since then we have given him a further course of Tryparsamide, gm. I2. The disease appears arrested and he has been advised to return to work (electrician).

No. 28.-Male, aged 4I. Primary infection I909. Then $\mathrm{Hg}$ two courses. N.A.B. three courses in the Navy. First seen I6.II.27, with the history that a few weeks before he had suddenly become unconscious and had been very confused on coming round. $\mathrm{He}$ was discharged from the Navy.

Mentally.-Ideation and memory good. Slight slurring speech.

Physically.-Left pupil Argyll Robertson. Right showed sluggish reaction to light. $A$ mask-like countenance. Slight trombone movement of tongue. No tabetic signs. Wassermann ++ (serum).

Tryparsamide, gm. I2, had been given by 4.I.28. Marked and steady improvement ensued from the first.

24.4.28. Second course of Tryparsamide, with bismuth in I c.c. doses. By II.7.28 Tryparsamide, gm. I2, and bismuth, I3 c.c., had been given.

A third course of Tryparsamide, gm. I2, finished on 24.I0.28. He was at work on a poultry farm soon after the completion of his first course of Tryparsamide and now shows no mental signs, looks much more alert and has almost lost his slurring speech.

The disease appears entirely arrested, with little or no resulting disability.

No. 30.-Male, aged 4I. Patient first seen II.I.28. No history or treatment.

Mentally.-Ideation was very slow and he was confused. Memory was very poor, and a slurring speech was present. 


\section{SOME NOTES ON TRYPARSAMIDE THERAPY}

Physically.-Pupils normal. All muscle jerks very brisk. No ataxia. Patient had a very sallow appearance and a greasy skin.

Wassermann ++ (blood)

He was given a course of N.A.B. and bismuth and much improved.

12.5.28. Course of Tryparsamide started. Further improvement. Patient is now back at work and as well as ever before. Painter, has been busy all through the slack season, painting doors, windows and other difficult work. It is not fair to claim the whole credit for Tryparsamide treatment in this case, as marked improvement occurred with the first course of N.A.B. and bismuth.

No. 33. Male, aged 33. No history of syphilitic infection. I.6.27, patient had an acute maniacal attack. He showed no physical signs and was admitted to the Maudsley Hospital. There the diagnosis of G.P.I. was made.

Wassermann of blood and C.S.F. was found to be positive. Treated with Tryparsamide and then malaria.

Attended the Clinic 29.2.28, showed no physical signs, mentally a little self-satisfied.

Given two courses of Tryparsamide ending Io.IO.28. During the courses the patient returned to work (gentleman's servant) and showed increasing steadiness, power of application and energy. Could not now be said to suffer from any disability. This is an interesting recovery from the acute state of excitement in which he was in the Maudsley, but, of course, two points must be emphasised, the liability of this type of G.P.I. to spontaneous remissions and the treatment with malaria.

No. 32.-Male, aged 24. Ex-soldier. Father died of G.P.I. Mother not tested. Denies syphilitic infection.

August, 1927, had an attack of acute confusional insanity, during Army manœuvres and following exposure to cold and wet. Treated in army hospital until he recovered, and then given six injections before discharge.

Attended I8.r.28. Showed a very expressionless face, a slightly slurred speech, Argyll Robertson pupils, insensitive calves.

Wassermann ++ (serum).

Mentally.-He was rather truculent in manner, did not want treatment, said that he was quite well, and had 


\section{BRITISH JOURNAL OF VENEREAL DISEASES}

very imperfect insight into the nature of the hallucinations which he described.

After one course of Tryparsamide and bismuth, patient was mentally quite normal and had found work.

A second course of Tryparsamide was completed 28.7.28. Mentally normal. The pupils now reacted slightly to light, and the left calf was more sensitive to pressure.

This case is one who a few years ago would have been given a hopeless prognosis. He is the only case in whom the physical signs seem to have been favourably influenced by treatment. A third course of Tryparsamide has been begun.

No. 20.-Male, aged 52. Newsvendor. First seen December, I926. Infection more than thirty years ago. Very confused, depressed, occasionally violent. Used to start early on his newspaper rounds, often before the papers arrived.

One course of Bismostab (I2 c.c.) had no beneficial effect. After I4 gm. of Tryparsamide he improved greatly and could get about alone, though he never was much use in the shop again.

He had severe arsenical dermatitis seven weeks after the last injection. This cleared up with thiosulphate.

October, I928. Still manageable, but definitely relapsing. Cannot be persuaded to come to the Clinic.

Miscellaneous Group.-The results are not important ; one case improved, one is unchanged and one is very much worse.

\section{Complications}

The table shows the complications which occurred out of thirty-three cases of neurosyphilis and fifteen cases treated with Tryparsamide because they showed persistent Wassermann reactions.

The complications were, for the most part, trivial. The eye symptoms, headache, sickness and influenzal reactions cleared up on stopping the treatment. The jaundice and dermatitis cases were cured with thiosulphate.

Exacerbation of symptoms. gave us the most trouble. This began with intense pain in the legs and was followed, in the two tabetic cases, with marked increase of ataxia. One of these cases is reported above (see No. II). 


\section{SOME NOTES ON TRYPARSAMIDE THERAPY}

\section{Further Observations from the Tables}

Dissection of the tables shows a few facts of interest. Of the thirty-three cases, nineteen gave a history of primary syphilis. Ten of these cases had initial treatment with $\mathrm{Hg}$, one with $\mathrm{Hg}$ and salvarsan, one with salvarsan alone, and seven had no initial treatment. Adding this figure (seven) to the number of cases who denied syphilitic infection, we arrive at the figure twentyone as the number who had no initial treatment. The treatment of the others was trivial with the exception of two cases, No. 2 and No. 28.

The length of time between the primary stage and the development of nervous symptoms varied from six to thirty years; the average was nineteen years.

\section{Summary}

(I) Twenty-four cases of tabes, six cases of G.P.I. and three miscellaneous cases of neurosyphilis have been treated during the last two years with Tryparsamide in the Out-patient Venereal Disease Department of the Royal Berkshire Hospital.

(2) Tryparsamide has given much better results than the arsenobenzol compounds.

Eleven cases of tabes showed slight and seven marked improvement. Several cases of trophic ulcer improved after resisting every form of treatment.

All the G.P.I. cases greatly benefited, and five out of the six are at work. We wish to emphasise the value of Tryparsamide in early G.P.I.

One of the miscellaneous cases also improved.

(3) The treatment is simple, suitable for the general practitioner and for the out-patient department, and, if proper precautions are taken, the complications need not be feared.

\section{REFERENCES}

(I) I. T. DAviEs. Lancet, I926, ii, p. I3I6.

(2) Neymann and Singleton. United States V. B. Med. Bulletin, May, I926, p. 435 .

(3) Moore and Sutron. Journal of Nervous and Mental Disease, June, I926, p. 574. 